\title{
Environmental Risk Due to Heavy Metal Contamination Caused by Old Copper Mining Activity at Lubietová Deposit, Slovakia
}

\author{
Peter Andráś ${ }^{1,2}$, Ingrid Turisová ${ }^{1}$, Eva Lacková ${ }^{3}$, Sherif Kharbish ${ }^{4}$, Jozef Krnáć ${ }^{1} \&$ Lenka Čmielová $^{3}$ \\ ${ }^{1}$ Faculty of Natural Sciences, Matej Bel University, Banská Bystrica, Slovakia \\ ${ }^{2}$ Geological Institute of Slovak Academy of Sciences, Banská Bystrica, Slovakia \\ ${ }^{3}$ VŠB-Technical University of Ostrava, Ostrava, Czech Republic \\ ${ }^{4}$ Geology Department, Faculty of Science, Suez University, Suez Governate, El Salam City, Egypt \\ Correspondence: Peter Andráš, Geological Institute of Slovak Academy of Sciences, Banská Bystrica, Slovakia. \\ Tel: 421-048-412-3943.E-mail: andras@savbb.sk
}

Received: September 18, 2012 Accepted: October 16, 2013 Online Published: November 22, 2013

doi:10.5539/eer.v3n2p182

URL: http://dx.doi.org/10.5539/eer.v3n2p182

\begin{abstract}
The more than 200 years old dump-fields at closed $\mathrm{Cu}(\mathrm{Ag})$ deposit Lubietová are situated near the village settlement. Heavy metal space distribution is controlled by geochemical behaviour of the elements, depend on their content, solubility, migration and sorption ability. The major sources of metals to the country components (soil, technogenous sediments, groundwater, surface water, plants...) may be classified according to expected solubility of primary minerals. The content of heavy metals in sediments and soils at the studied dump-field shows irregular distribution. Also the heavy metal contamination of the surface water and groundwater was studied both in the rainy as well as during the dry periods. The speciation of As and $\mathrm{Sb}$ proved in the water presence both of $\mathrm{As}^{3+}$ and $\mathrm{Sb}^{3+}$ as well as the less toxic $\mathrm{As}^{5+}$ and $\mathrm{Sb}^{5+}$ species. In the soil and sediments prevail $\mathrm{As}^{5+}$ and $\mathrm{Sb}^{5+}$ species while in the water is often dominant the $\mathrm{As}^{3+}$ and $\mathrm{Sb}^{3+}$ form. The article also presents some results of the plant tissue degradation study under heavy metal contaminated conditions at dump-fields. The dump sediments and the primitive soil formed locally on the surface of the technogenous sediments show only limited acidification potential. The $\mathrm{Fe}^{0}$-barrier installation at bottom of the down part of the valley seems to be a good solution for the groundwater decontamination.
\end{abstract}

Keywords: acidification, heavy metal contamination, dump-field, impact on flora, remediation

\section{Introduction}

The Lubietová deposit was exploited since the time of the Bronze Age and in the 16th and 17th centuries it was one of the most important and most extensively exploited $\mathrm{Cu}$-mines of Europe. The $\mathrm{Cu}$-ore was in the 18. century exported to more than 50 countries (Bergfest, 1951). The $\mathrm{Cu}$ mineralisation with Ag admixture is developed within 4-5 km long and $1.5 \mathrm{~km}$ wide range of N-S direction. It is situated in a crystalline complex which consists of arcose greywackes, arcose schists and various conglomerates. The ore mineralisation was genetically connected with the basic, intermediate and acid Permian volcanism. It is characterised by a rather simple paragenesis represented by quartz, siderite, chalcopyrite, Ag-tetrahedrite, arsenopyrite, pyrite and rare galena. The deposit is famous also by the numerous secondary minerals as libethenite, annabergite, langite, azurite, brochantite, erithrine, evansite, euchroite, cuprite, malachite, olivenite, pseudomalachite, etc. (Koděra et al., 1990; Ebner et al., 2004). There are three great ore-fields at Lubietová: Podlipa, Svätodušná and Kolba with admixture of $\mathrm{Co} / \mathrm{Ni}$-mineralisation. The $\mathrm{Cu}$ content in the ore ranged from $4-10 \%$ and the $\mathrm{Ag}$ content was about $70 \mathrm{gt}^{-1}$ (Bergfest, 1951).

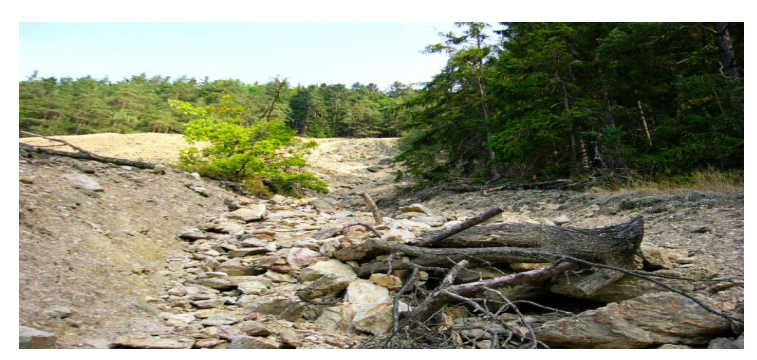


Figure 1. Dump-field podlipa at abandoned Cu-deposit L'ubietová

The extent of the dump-field Podlipa (Figure 1) is about $2 \mathrm{~km}^{2}$. This ore-field was exploited by 18 adits. The $\mathrm{Cu}$-ore mineralisation is situated mainly in the terrigene crystalline complex of Permian age which consists of arcose greywackes, arcose schists and various conglomerates. The most important tectonic structures are of NE-SW direction and the ore veins have E-W and N-S direction. They are 30-40 $\mathrm{m}$ thick.

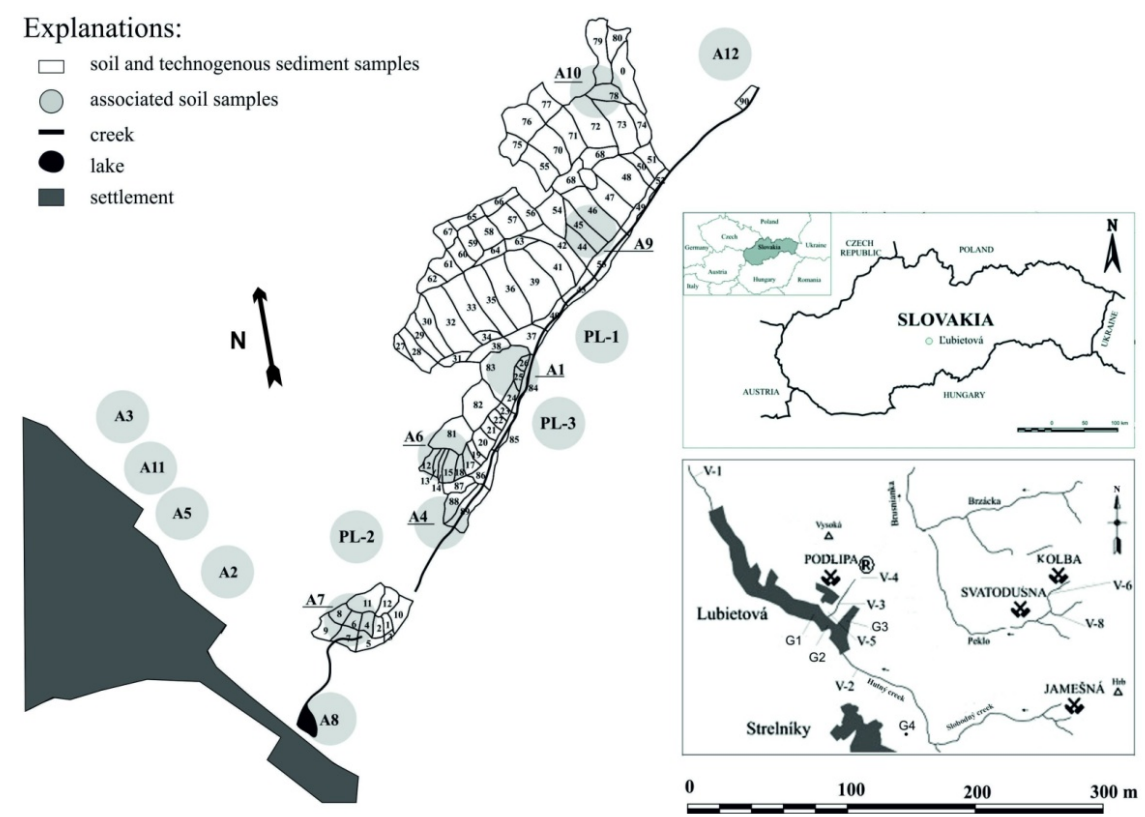

Figure 2. The Podlipa dump-field: localisation of the soil (samples A-1 to A-12 and 1-80) and water (samples V, CD and LH) sampling

The important mining stopped in the second half of the 19th century although the last little gallery near Haliar locality was exploited by Ernest Schtróbl only in April 1915.

\section{Material and Methods}

The technogenous sediment and soil samples (of about $10 \mathrm{~kg}$ weight; samples 1-80 and A-1 to A-12 from the Podlipa dump-field and soils from 15-20 cm depth (the sampling step was about $25 \mathrm{~m}^{2}$ ) were collected in order to characterize components of landscape contamination. Next three samples PL-1 to PL-3 are samples of soil horizons (A, B, C). To each surface water sample (stream water, drainage water-samples V-1 to V-6) and groundwater samples (G-1 to G-4; Figure 2) $10 \mathrm{ml}$ of $\mathrm{HCl}$ was added to conservate them.

The reference site was located above the ore-field (Figure 2, sample A-12), outside of geochemical anomalies of heavy metals and represent graywakes of Permian age similar to material at the dump-field. Plant samples were collected both from reference area and from the dump-area.

The samples of technogenous sediments and soil from the dumps were dried and $0.25 \mathrm{~g}$ of sample was heated in $\mathrm{HNO}_{3}-\mathrm{HClO}_{4}-\mathrm{HF}$ to fuming and taken to dryness. The residue was dissolved in $\mathrm{HCl}$. Solutions were analysed by ICP-MS analysis at the ACME Analytical Laboratories (Vancouver, Canada). The minerals in the clay fractions were determined by X-ray diffraction and the clay mineral samples were ICP-MS analysed, then macerated 14 days in natural drainage water of the studied locality containing heavy metals and analysed again. The $\mathrm{pH}$ of the sediments was determined from suspension both with distilled water and $1 \mathrm{M} \mathrm{KCl}$ after 3 hours of maceration.

The sulphur, total carbon, organic carbon and inorganic carbon content in the sediments was IR analysed using furnace Ströhlein C-MAT 4000 at the laboratories of Geological Institute of Slovak Academy of Sciences. A static test of the total acid potential was realized according to Morin and Hutt (1997) and Sobek et al. (1978). The water samples were analysed using AAS in the National Water Reference Laboratory for Slovakia at the Water Research Institute in Bratislava. The speciation of As was performed on the basis of different reaction rate of $\mathrm{As}^{3+}$ and $\mathrm{As}^{5+}$ depending on $\mathrm{pH}$ and $\mathrm{Eh}$. The experimental study on $\mathrm{Cu}$ precipitation on the surface of iron particles (testing of the $\mathrm{Fe}^{0}$-barrier) mixed with dolomite was realized at the laboratory of the Comenius University in Bratislava by Dr. Bronislava Lalinská according to Bartzas (2006).

\section{Results}

\subsection{Heavy Metal Contamination of Technogenous Sediments and Soil}


The dump-field technogenous sediments are influenced by heavy metals (Table 1) from the hydrothermal ore mineralisation. The main contaminants are: $\mathrm{Cu}$ (up to $20360 \mathrm{ppm}$ ), $\mathrm{Fe}$ (up to 2.58\%), As (up to $457 \mathrm{ppm}$ ), $\mathrm{Sb}$ (up to 79.3 ppm) and $\mathrm{Zn}$ (up to $80 \mathrm{ppm}$ ) are accompanied also by U (up to $10 \mathrm{ppm}$ ) and Th (up to $35 \mathrm{ppm}$ ) from the Permian volcano-sedimentary metamorphosed rocks.

Table 1. ICP-MS analyses of technogenous sediments and soils from the dump-field

\begin{tabular}{|c|c|c|c|c|c|c|c|c|c|}
\hline Sample & $\mathrm{Cu}$ & $\mathbf{P b}$ & Zn & $\mathbf{N i}$ & $\begin{array}{r}\text { Co } \\
\text { ppm }\end{array}$ & As & $\mathbf{S b}$ & $\mathbf{B i}$ & $\mathbf{U}$ \\
\hline A-1 & 2829 & 28.1 & 14 & 36.8 & 10.4 & 162 & 61.6 & 2.8 & 1.3 \\
\hline A-1c & 1693 & 63.8 & 18 & 36.0 & 11.3 & 258 & 60.1 & 4.5 & 1.4 \\
\hline A-1c* & 2345 & 229.1 & 95 & 71.8 & 18.3 & 628 & 153.2 & 14.6 & 3.3 \\
\hline A-2 & 198.8 & 13.0 & 21 & 9.8 & 5.9 & 10 & 7.1 & 0.2 & 1.4 \\
\hline$A-2 c$ & 574.3 & 22.4 & 36 & 12.2 & 10.3 & 19 & 9.2 & 1.4 & 1.1 \\
\hline$A-2 c^{*}$ & 472.4 & 27.9 & 62 & 17.0 & 6.4 & 15 & 12.6 & 1.5 & 1.1 \\
\hline A-3 & 827.5 & 16.0 & 20 & 32.1 & 14.0 & 71 & 22.4 & 8.5 & 1.7 \\
\hline$A-3 c$ & 624.2 & 23.1 & 25 & 28.3 & 17.0 & 110 & 24.0 & 7.2 & 1.8 \\
\hline$A-3 c^{*}$ & 857.4 & 37.4 & 47 & 30.4 & 11.0 & 105 & 28.0 & 12.1 & 1.9 \\
\hline A-4 & 4471 & 9.6 & 23 & 55.0 & 50.0 & 169 & 59.5 & 23.7 & 1.6 \\
\hline$A-4 c$ & 3324 & 14.9 & 16 & 42.4 & 58.3 & 237 & 79.3 & 39.2 & 1.7 \\
\hline$A-4 c^{*}$ & 3112 & 37.8 & 27 & 64.4 & 32.1 & 300 & 129.8 & 90.9 & 2.2 \\
\hline A-5 & 3150 & 16.9 & 19 & 34.0 & 24.4 & 60 & 17.2 & 1.7 & 1.0 \\
\hline$A-5 c$ & 3001 & 14.8 & 18 & 34.1 & 30.4 & 64 & 16.3 & 2.1 & 1.2 \\
\hline$A-5 c^{*}$ & 2078 & 21.9 & 45 & 55.4 & 29.6 & 105 & 30.3 & 3.2 & 1.4 \\
\hline A-6 & 4797 & 15.6 & 13 & 51.6 & 41.8 & 134 & 49.8 & 25.4 & 1.4 \\
\hline$A-6 c$ & 2503 & 24.6 & 14 & 45.1 & 40.9 & 224 & 56.2 & 24.4 & 1.6 \\
\hline A-6c* & 2918 & 72.3 & 65 & 61.7 & 32.0 & 305 & 92.3 & 51.7 & 2.2 \\
\hline A-7 & 755.8 & 16.8 & 26 & 10.4 & 10.2 & 16 & 11.5 & 0.9 & 1.1 \\
\hline$A-7 c$ & 855.1 & 20.2 & 33 & 10.1 & 12.0 & 17 & 7.1 & 1.2 & 1.1 \\
\hline$A-7 c^{*}$ & 2026 & 73.7 & 176 & 26.0 & 15.5 & 33 & 17.4 & 3.6 & 2.3 \\
\hline A-8 & 716.0 & 6.5 & 7 & 58.0 & 89.9 & 61 & 17.9 & 0.5 & 2.6 \\
\hline$A-8 c$ & 835.5 & 6.3 & 14 & 66.5 & 69.7 & 52 & 20.2 & 0.7 & 2.5 \\
\hline A-8c* & 836.7 & 4.2 & 4 & 62.5 & 104.5 & 46 & 18.9 & 0.8 & 2.1 \\
\hline A-9 & 5903 & 29.5 & 24 & 39.8 & 36.0 & 244 & 37.0 & 15.1 & 2.7 \\
\hline A-10 & 7699 & 30.2 & 19 & 52.2 & 48.0 & 457 & 62.7 & 25.1 & 4.0 \\
\hline A-11 & 1563 & 24.8 & 37 & 19.0 & 8.7 & 16 & 14.9 & 4.8 & 1.7 \\
\hline A-12 & 113.1 & 39.4 & 29 & 8.9 & 8.6 & 16 & 5.6 & 0.7 & 1.4 \\
\hline A-17 & 14440 & 8.4 & 59 & 51.7 & 73.4 & 289 & 43.2 & 7.2 & 2.3 \\
\hline$A-17 c$ & 20360 & 49.0 & 80 & 43.0 & 70.0 & 260 & 40.0 & 6.0 & 2.0 \\
\hline
\end{tabular}

Explanations: A-1 to A-11 - technogenous sediments and soils from the dump-field, A-12 reference area, A-17 hydrogoethite, A-1c to A-17c clay fraction, A-1* to A-17* - clay fraction after 14 days maceration in drainage water, containing heavy metals.

The weathering processes of reactive minerals in surrounding and mainly acid rocks mobilise heavy metals and toxic elements (e.g. $\mathrm{Cu}, \mathrm{As}$ ) from the primary minerals (Figure 4), form secondary minerals (mainly Cu-oxides and arsenates Figure 5, Fe hydroxides - Figure 6 and carbonates - Figure 7) and contaminate the landscape components.

The main $\mathrm{Cu}$ concentration was found to be near the Najvyššia Johan gallery collar, inclusive of the slope beneath the gallery. High $\mathrm{Cu}$ concentration is at the bottom of the valley (Figure 3a). The most important source of As and Fe are the galleries Najvyššia Johan, Horná Johan and Stredná Johan (Figures 3b, 3c). The highest Pb concentration was found in front of the Zollweiner Maria Empfängnis and Jakob galleries collars (Figure 3d). Th contamination is derived from Francisci and Bartolomej galleries (Figure 3e) and important Sb contamination was detected mainly at the dumps at Zollweiner Maria Empfängnis gallery (Figure 3f). 


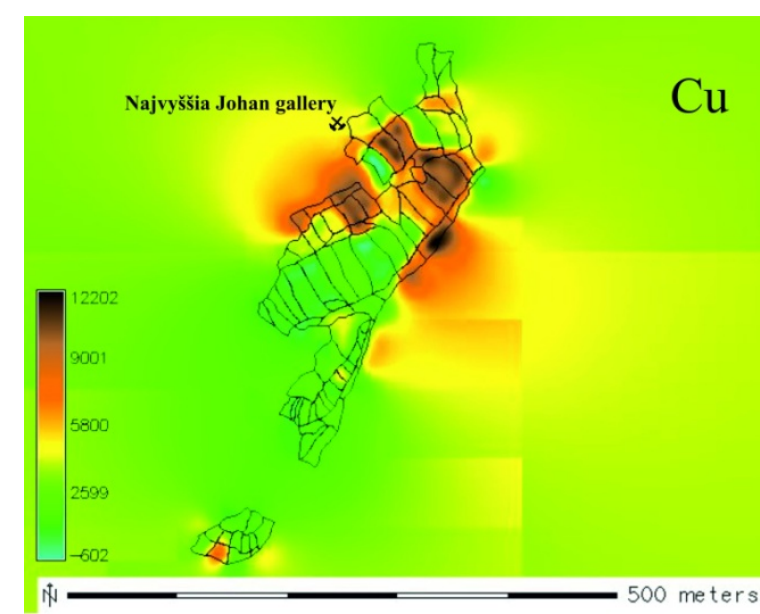

a)

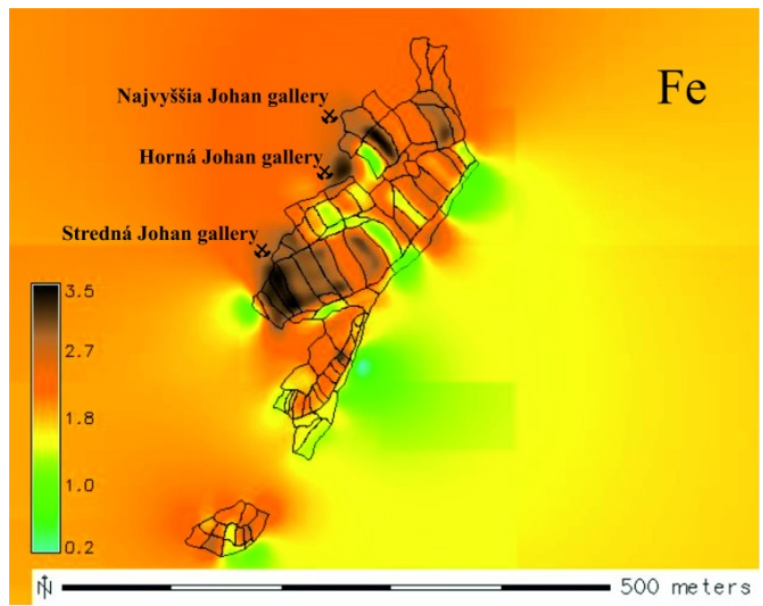

c)

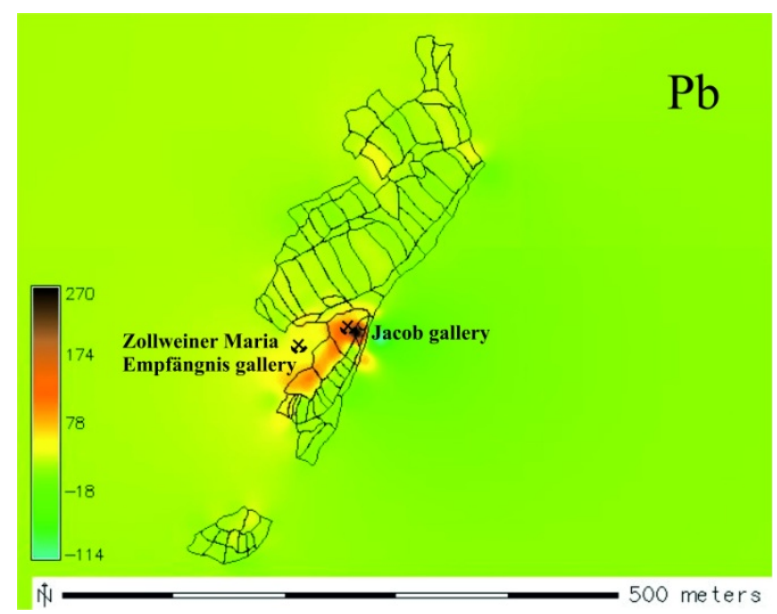

e)

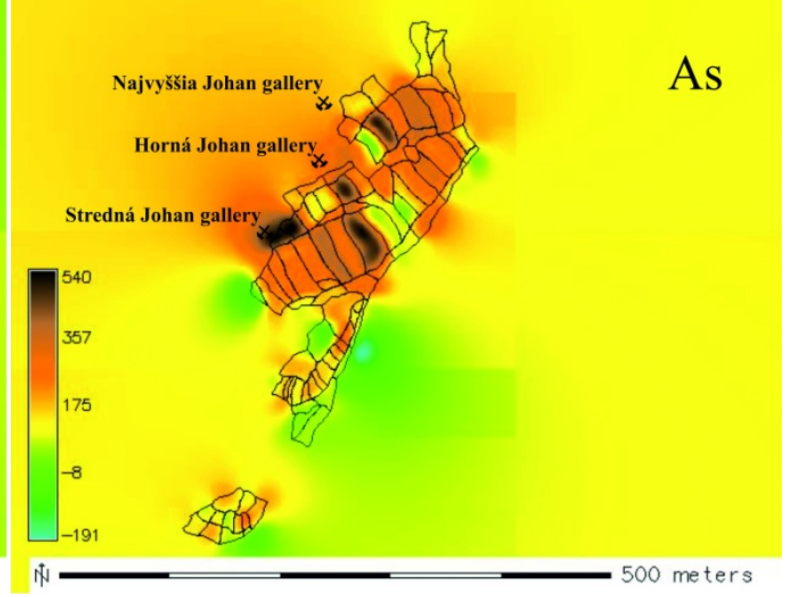

b)

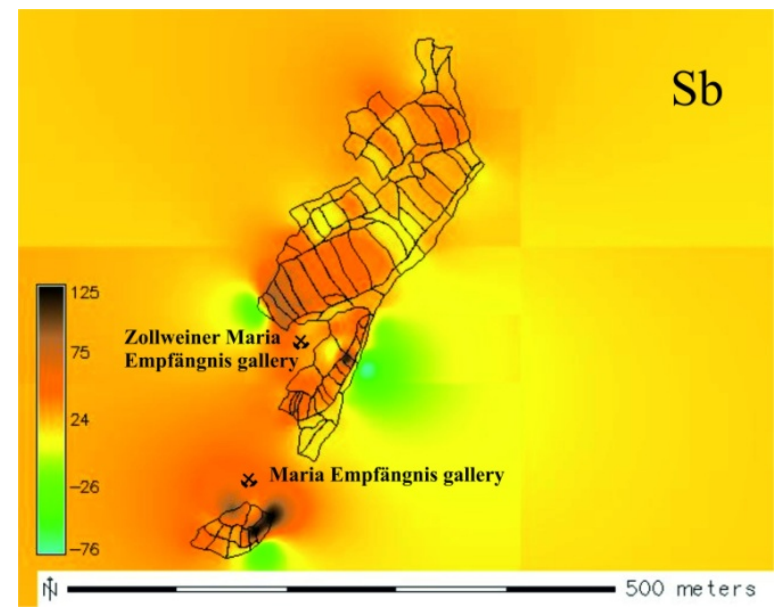

d)

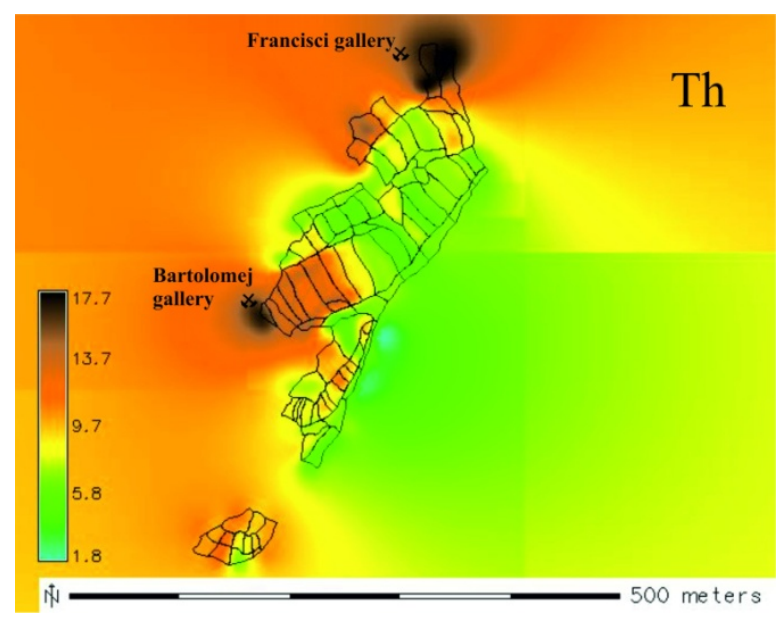

f)

Figure 3. Distribution of heavy metals at the Podlipa dump-field: $\mathrm{Cu}, \mathrm{As}, \mathrm{Fe}, \mathrm{Pb}, \mathrm{Th}, \mathrm{Sb}$-distribution (numbers show the individual heavy metal content in ppm) 
In mould horizon $\mathrm{A}$ are accumulated $\mathrm{Ca}, \mathrm{P}, \mathrm{Pb}, \mathrm{Zn}, \mathrm{Cd}, \mathrm{Cr}$ and Th. In soil horizont $\mathrm{B}$ folowing elements: $\mathrm{Cu}, \mathrm{Ag}, \mathrm{Ni}$ and As are accumulated in clay minerals and sesquioxides. The $\mathrm{C}$ horizon is enriched in $\mathrm{Ba}$ (Table 2). The other analysed elements (e.g. Fe, Mg, Ti, Al, Na, K, Mo, Mn, U) show no unambiguous trend to be accumulated in some soil horizon. $\mathrm{The} \mathrm{Sb}, \mathrm{Bi}$ and $\mathrm{Co}$ concentrations in individual soil horizons show no unambiguous trends.

Table 2. ICP-MS analyses of individual soil horizons

\begin{tabular}{|c|c|c|c|c|c|c|c|c|c|}
\hline \multirow{2}{*}{ Sample } & \multirow{2}{*}{ Horizon } & $\mathbf{F e}$ & Ca & $\mathbf{P}$ & Mg & $\mathbf{T i}$ & Al & $\mathbf{N a}$ & K \\
\hline & & \multicolumn{8}{|c|}{$\%$} \\
\hline \multirow{3}{*}{ PL-1 } & A & 2.48 & 0.40 & 0.093 & 0.62 & 0.155 & 5.98 & 0.328 & 3.02 \\
\hline & B & 2.01 & 0.27 & 0.090 & 0.59 & 0.125 & 6.01 & 0.269 & 3.37 \\
\hline & $\mathrm{C}$ & 2.05 & 0.17 & 0.067 & 0.50 & 0.146 & 6.41 & 0.344 & 3.74 \\
\hline \multirow{3}{*}{ PL-2 } & A & 3.02 & 0.33 & 0.097 & 0.42 & 0.099 & 5.81 & 0.321 & 3.05 \\
\hline & B & 2.49 & 0.22 & 0.058 & 0.45 & 0.084 & 6.06 & 0.496 & 3.43 \\
\hline & $\mathrm{C}$ & 6.87 & 0.12 & 0.053 & 0.26 & 0.093 & 5.73 & 0.122 & 3.01 \\
\hline \multirow{3}{*}{ PL-3 } & A & 1.32 & 0.49 & 0.092 & 0.56 & 0.083 & 4.45 & 0.052 & 2.24 \\
\hline & B & 1.65 & 0.05 & 0.076 & 0.44 & 0.097 & 5.58 & 0.043 & 3.03 \\
\hline & $\mathrm{C}$ & 2.01 & 0.11 & 0.077 & 0.66 & 0.154 & 4.73 & 0.022 & 4.01 \\
\hline \multirow{2}{*}{ Sample } & \multirow{2}{*}{ Horizon } & $\mathrm{Cu}$ & $\mathbf{P b}$ & $\mathbf{Z n}$ & Ag & $\mathbf{N i}$ & Cd & As & Sb \\
\hline & & \multicolumn{8}{|c|}{ ppm } \\
\hline \multirow{4}{*}{ PL-1 } & A & 5864 & 32.6 & 136 & 7.6 & 38 & 0.7 & 1010 & 2449 \\
\hline & B & 9425 & 33.3 & 130 & 8.5 & 40.9 & 0.4 & 1081 & 2356 \\
\hline & C & 3633 & 10.4 & 89 & 4.7 & 36.7 & 0.2 & 497 & 1159 \\
\hline & A & 4462 & 33.9 & 133 & 5.3 & 27.5 & 1.1 & 553 & 1216 \\
\hline \multirow[t]{2}{*}{ PL-2 } & B & 8230 & 17.2 & 134 & 6.8 & 33.6 & 0.5 & 884 & 1539 \\
\hline & $\mathrm{C}$ & 6059 & 8.1 & 142 & 10 & 33 & 0.3 & 565 & 1704 \\
\hline \multirow{3}{*}{ PL-3 } & A & 3366 & 66 & 77 & 1.1 & 30.8 & 1.1 & 77 & 24 \\
\hline & B & 8085 & 15.1 & 11 & 2.2 & 36.3 & 0.1 & 231 & 23 \\
\hline & $\mathrm{C}$ & 5115 & 15.1 & 16 & 1.2 & 34.3 & 0.2 & 158 & 37 \\
\hline \multirow{2}{*}{ Sample } & \multirow{2}{*}{ Horizon } & Mo & Mn & Co & $\mathbf{B i}$ & $\mathrm{Cr}$ & Ba & $\mathbf{U}$ & Th \\
\hline & & \multicolumn{8}{|c|}{$\mathrm{ppm}$} \\
\hline \multirow{4}{*}{ PL-1 } & A & 0.7 & 1033 & 46.5 & 122 & 31 & 607 & 5.4 & 9.2 \\
\hline & B & 1.2 & 953 & 43.8 & 112.1 & 26 & 694 & 6.1 & 6.9 \\
\hline & C & 0.7 & 765 & 26.5 & 42.9 & 19 & 705 & 3.3 & 7.3 \\
\hline & A & 0.9 & 1123 & 32.8 & 49.4 & 22 & 620 & 3.2 & 7.5 \\
\hline \multirow[t]{3}{*}{ PL-2 } & B & 0.4 & 1171 & 49.2 & 70.3 & 13 & 841 & 3.2 & 6.3 \\
\hline & $\mathrm{C}$ & 0.7 & 2220 & 20.1 & 37.4 & 20 & 1099 & 3.5 & 7.3 \\
\hline & A & 3.3 & 352 & 35.2 & 3.3 & 18 & 218 & 1.4 & 4.9 \\
\hline \multirow[t]{2}{*}{ PL-3 } & B & 3.3 & 253 & 45.1 & 8.1 & 11 & 283 & 2.9 & 6.7 \\
\hline & $\mathrm{C}$ & 0.3 & 351 & 48.8 & 8.6 & 13 & 303 & 3.3 & 7.7 \\
\hline
\end{tabular}

The distribution of individual metals at the studied dump-field is uneven. It depends on the mineralogical composition of ores, on the original concentration of the mentioned metals in the technogenic sediments of the spoil dumps, and also on their migration abilities and sorption properties (Figure 3). At Podlipa were described only few correlations between metal couples (Ni/As, $\mathrm{Fe} / \mathrm{Ni}, \mathrm{Pb} / \mathrm{Cd}, \mathrm{Co} / \mathrm{Cu}$., $\mathrm{Zn} / \mathrm{Cd}, \mathrm{Zn} / \mathrm{Pb}, \mathrm{Cd} / \mathrm{Pb}$ ant $\mathrm{Th} / \mathrm{U}$ ). This situation substantially differs from the dump-field Reiner, where we can distinguish high correalition ratio between four times more element couples as at Podlipa (Andráš et al., 2009). The main reasons of this separate geochemical behaviour of the same elements at the two neighbour localities is the different rock-surrounding (homogenous rock-surrounding at Reiner locality built by greywakes vs. grauwakes - arcose schists rock composition at Podlipa, which form different quantity of natural sorbents as clay minerals; Andráš et al. (2009). The distribution of elements can be controlled also by formation of various metastable, secondary phases, which depend on $\mathrm{pH}$ and $\mathrm{Eh}$, eventually on ionic radius of elements. 


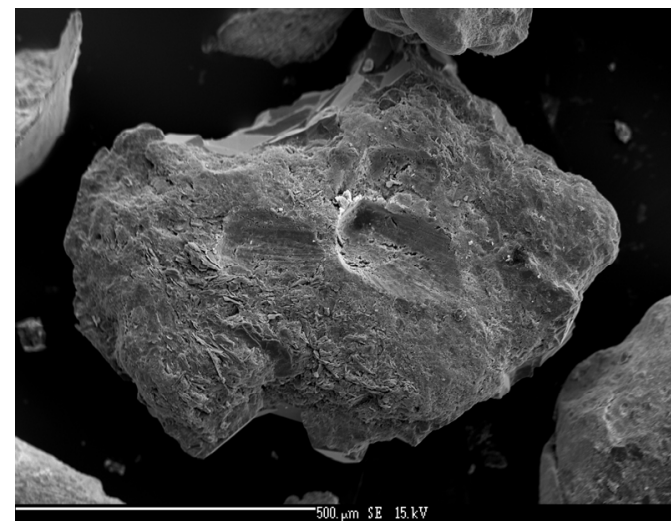

Figure 4. Grain of native copper

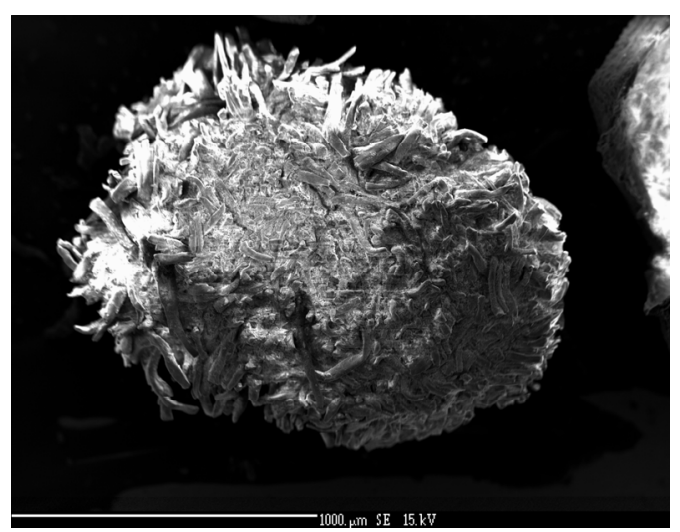

Figure 6. Lepidocrocite $(\gamma-\mathrm{FeO}(\mathrm{OH}))$ aggregat

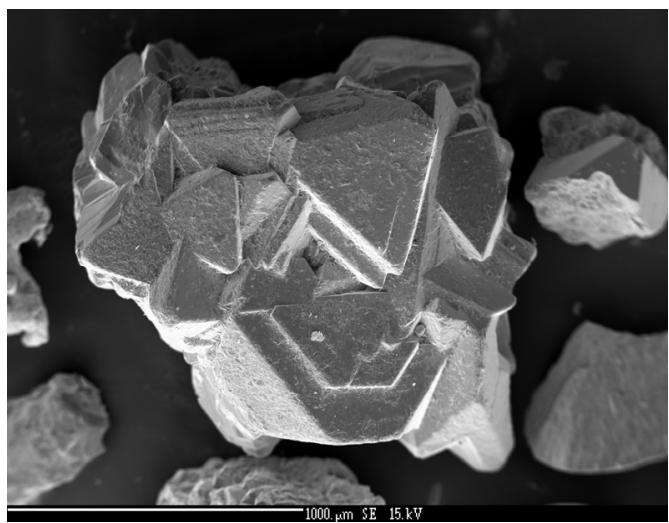

Figure 5. Euchoite $\left(\mathrm{Cu}_{2}\left(\mathrm{AsO}_{4}\right)(\mathrm{OH}) \cdot 3 \mathrm{H}_{2} \mathrm{O}\right)$ aggregate

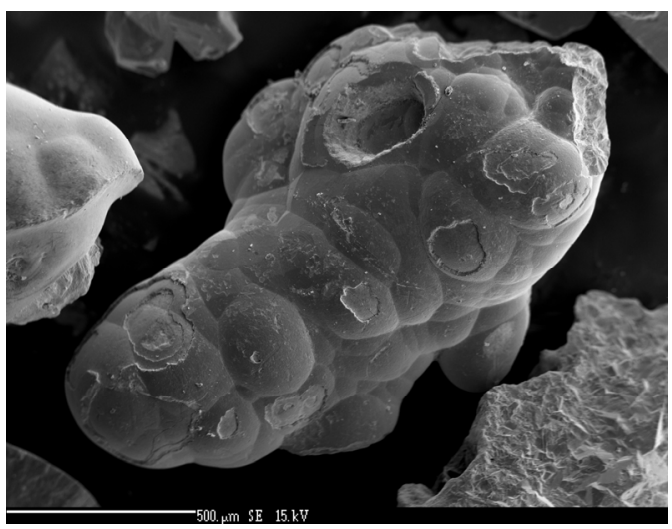

Figure 7. Malachite $\left(\mathrm{Cu}_{2} \mathrm{CO}_{3}(\mathrm{OH})_{2}\right)$ aggregate

\subsection{Heavy Metals in Water}

The surface water in the creek draining the valley bottom along the dump-field is gradually contaminated by heavy metals leached from the technogenous sediments of the mining dumps. This surface water contains high $\mathrm{Cu}$ (up to $2060 \mu \mathrm{g} \mathrm{L}^{-1}$ ), $\mathrm{Fe}$ (up to $584 \mu \mathrm{g} \cdot \mathrm{L}^{-1}$ ), $\mathrm{Zn}$ (up to $35 \mu \mathrm{g} \cdot \mathrm{L}^{-1}$ ) and sometimes also Co (up to $10 \mu \mathrm{g} \mathrm{L}^{-1}$ ) and $\mathrm{Pb}$ (up to $5 \mu \mathrm{gL}^{-1}$ ) concentrations. The highest As concentration is $6.11 \mu \mathrm{gL}^{-1}$ (Table 3).

Table 3. Atom absorption spectrometric analyses of surface water

\begin{tabular}{|c|c|c|c|c|c|c|c|c|c|c|c|c|}
\hline \multirow{2}{*}{ Sample } & \multirow{2}{*}{ pH } & Eh & Mn & $\mathbf{Z n}$ & Cd & Co & $\mathrm{Cu}$ & $\mathbf{F e}$ & $\mathrm{Ni}$ & $\mathbf{P b}$ & $\mathbf{S b}$ & As \\
\hline & & $(\mathrm{mV})$ & \multicolumn{10}{|c|}{$\mu \mathrm{g} .1^{-1}$} \\
\hline V-1a & 6.5 & -6 & $<1$ & $<10$ & 0.04 & 1.1 & 2.2 & 26 & 4.1 & 4.2 & 0.74 & $<1.0$ \\
\hline$V-1 b$ & 7.5 & -58 & $<1$ & $<10$ & 0.05 & 2.2 & 2.7 & 73 & 5.9 & 4.3 & $<1.00$ & $<1.0$ \\
\hline$V-1 c$ & 6.5 & -8 & 11 & $<10$ & $<0.05$ & $<1.0$ & 5.1 & 94 & 1.2 & $<1.0$ & 1.03 & $<1.0$ \\
\hline$V-2 b$ & 6.7 & -14 & $<1$ & $<10$ & 0.13 & $<1.0$ & 42.1 & 584 & 2.1 & 3 & $<1.00$ & 1.69 \\
\hline$V-2 c$ & 6.9 & -21 & $<1$ & $<10$ & 0.09 & $<1.0$ & 38.2 & 580 & 1.6 & 2.9 & $<1.00$ & 1.54 \\
\hline$V-3 a$ & 6.7 & -12 & $<1$ & 30 & 0.04 & 7 & 1810 & 86 & 3.2 & 2.2 & 1.12 & $<1.00$ \\
\hline$V-3 b$ & 6.1 & 14 & $<1$ & 40 & 0.05 & 9.6 & 2060 & 101 & 4.9 & 2.8 & 1.88 & 3.41 \\
\hline$V-3 c$ & 6.5 & 0 & 21 & $<10$ & $<.05$ & 7.6 & 1980 & 45 & 8.5 & 2.8 & 2.35 & 1.14 \\
\hline$V-4 a$ & 6.7 & -14 & $<1$ & $<10$ & 0.06 & 3.1 & 22.2 & 263 & 2.1 & 4.2 & 1.72 & $<1.0$ \\
\hline$V-4 b$ & 6.2 & 14 & $<1$ & $<10$ & 0.06 & 8.1 & 1850 & 274 & 5.6 & 3.6 & 1.57 & 1.21 \\
\hline V-5a & 6.2 & -11 & $<1$ & $<10$ & 0.06 & 5.5 & 6 & 170 & 6 & 4.8 & 1.66 & 2.79 \\
\hline $\mathrm{V} 5 \mathrm{~b}$ & 6.3 & -8 & 7 & 20 & 0.08 & 8.3 & 7.9 & 210 & 7.1 & 5.1 & 2.21 & 3.21 \\
\hline$V-5 d$ & 6.2 & -7 & 4 & 30 & 0.07 & 6.6 & 8.1 & 160 & 8.1 & 1 & 2 & 1.08 \\
\hline V-6a & 7.6 & -62 & $<1$ & 30 & 0.07 & 1.9 & 30.4 & 270 & 4.3 & 3.2 & 2 & 6.02 \\
\hline$V-6 b$ & 7.1 & -62 & $<1$ & 32 & 0.07 & 2.2 & 34.8 & 263 & 5 & 3.4 & 2.01 & 6.11 \\
\hline
\end{tabular}


Explanations: Samples marked by index "a" - rainy period (June 14 $\left.4^{\text {th }}, 2006\right)$, samples marked by index "b" - dry period (February $\left.25^{\text {th }}, 2007\right)$, samples marked by index "c" - rainy period (March 31 st 2008), samples marked by index "d" - dry period (May $27^{\text {th }}, 2008$ ).

The heavy metals content in the water is in most cases higher during dry periods than during rainy periods. On the other hand, the As content both in the surface (and drainage) water as well as in the groundwater is not high $\left(6.11 \mu \mathrm{gL}^{-1}\right.$; Table 3). The presence of Acidithiobacteria species or of sulphate reducing bacteria was not proved. The $\mathrm{pH}$ both of the surface and of groundwater is close to neutral values ( $\mathrm{pH}$ 6.4-7.6).

The most contaminated is the mineral water from the spring Linhart (sample G-4; Figure 2). Its total radioactivity is $6,498 \mathrm{~Bq}^{-1}$ and the $\mathrm{Fe}\left(380 \mu \mathrm{g} \cdot \mathrm{L}^{-1}\right), \mathrm{Cu}\left(181 \mu \mathrm{g} \cdot \mathrm{L}^{-1}\right), \mathrm{Pb}\left(1 \mu \mathrm{gL}^{-1}\right)$ and $\mathrm{Cd}\left(82.0 \mu \mathrm{g}^{-1}\right)$ contents (Table 4) exceed the Slovak decrees No. 296/2005, No 354/2006 Coll.

Table 4. Atom absorption spectrometric analyses of groundwater (samples G-1,G-2 and G-3) and mineral water (sampleG-4)

\begin{tabular}{|c|c|c|c|c|c|c|c|c|c|c|c|c|}
\hline \multirow{2}{*}{ Sample } & \multirow{2}{*}{ pH } & Eh & $\mathbf{F e}$ & $\mathbf{N i}$ & Mn & $\mathbf{Z n}$ & $\mathrm{Cu}$ & Cd & $\mathbf{P b}$ & $\mathbf{B i}$ & As & Sb \\
\hline & & $(\mathrm{mV})$ & \multicolumn{10}{|c|}{$\mu \mathrm{g} . \mathrm{l}^{-1}$} \\
\hline G-1a & 6.55 & -4 & 11 & 1.1 & $<5$ & $<10$ & 22 & $<0.05$ & $<1.1$ & 1.36 & $<1$ & $<1.0$ \\
\hline G-1b & 6.63 & -10 & 17 & 1.2 & $<5$ & $<10$ & 1.3 & $<0.05$ & 1.9 & 1.55 & $<1$ & $<1.0$ \\
\hline G-2a & 6.72 & -14 & 366 & 1.3 & 18 & $<10$ & 3 & $<0.05$ & 1.3 & $<1.00$ & $<1$ & $<1.0$ \\
\hline G-2b & 6.23 & -16 & 210 & 1.5 & 8 & $<10$ & 2.2 & $<0.05$ & $<1.0$ & $<1.00$ & $<1$ & $<1.0$ \\
\hline G-3a & 6.85 & -21 & 146 & $<1.0$ & 15 & 61 & 14 & 0.13 & 3.4 & $<1.00$ & 5 & 1.42 \\
\hline G-3b & 6.55 & -23 & 120 & $<1.0$ & 17 & 350 & 5.9 & 0.1 & 3.3 & $<1.00$ & 1.52 & 1.21 \\
\hline G-4a & 6.4 & 4 & 380 & 5 & 20 & $<10$ & 30 & 0.5 & $<1.0$ & $<1.00$ & 1.98 & $<1.0$ \\
\hline G-4b & 6.48 & -2 & 2260 & $<1.0$ & 55 & $<10$ & 181 & 82 & $<1.0$ & $<1.00$ & 2.52 & $<1.0$ \\
\hline
\end{tabular}

Explanations: a - sampled on March 31st 2008 during the rainy period; $\mathrm{b}$ - sampled on May 27th 2008 during the dry period.

Table 5. Paste and rinse $\mathrm{pH}\left(\mathrm{H}_{2} \mathrm{O}\right.$ and $\left.1 \mathrm{M} \mathrm{KCl}\right)$, sulphur and carbon contents in samples of technogenous sediments and soils

\begin{tabular}{|c|c|c|c|c|c|c|c|c|c|c|c|c|c|}
\hline Sample & $\mathbf{p H}_{\mathbf{H} 20}$ & $\mathbf{E h}_{\mathrm{H20}}$ & $\mathbf{p H}_{\mathrm{KCl}}$ & $\mathbf{E h}_{\mathrm{KCl}}$ & $S_{\text {tot. }}$ & $\mathrm{S}_{\mathrm{SO} 4}$ & $\mathbf{S}_{\mathrm{s}}$ & $C_{\text {tot. }}$ & $\mathrm{C}_{\text {org. }}$ & $\mathbf{C}_{\text {inorg. }}$ & $\mathrm{CO}_{2}$ & $\mathrm{CaCO}_{3}$ & $\begin{array}{c}\text { TAP } \\
\left(\mathrm{kg} . \mathrm{t}^{-1}\right)\end{array}$ \\
\hline A-1 & 5.14 & 77 & 4.61 & 109 & 025 & & 0.15 & & 0.2 & 0.54 & 1.97 & 4.48 & 7.813 \\
\hline A- & & & & & & & & & & & & & 0.625 \\
\hline A-3 & & 9 & 4.2 & 131 & & & 0.0 & 0.6 & & & & & 3.125 \\
\hline A-4 & & 59 & & 66 & 0.33 & & 0.0 & 0.3 & 0.26 & & & & 10.313 \\
\hline A-5 & & 42 & & & & & 0. & 0.7 & & & & & 1.563 \\
\hline A- 6 & & 74 & & & & & 0.2 & & 0.27 & & & & 13.125 \\
\hline A- & & -84 & & -5 & & & 0. & & 0.1 & & & & 0.938 \\
\hline A & & 3 & & & & & & 0.4 & 13 & 0.32 & 1.17 & & 0.313 \\
\hline & & & & & & & & & & tr. & tr. & tr. & 0.938 \\
\hline & & 7 & & 78 & & & & & 0.46 & tr. & tr. & tr. & 1.25 \\
\hline & & 22 & & 30 & 0.1 & & 0.0 & 4.3 & 4.18 & 0.13 & 0.47 & 1.08 & 3.438 \\
\hline A-12 & 4.21 & 133 & 3.47 & 173 & 0.02 & 0.01 & 0.02 & 4.05 & 4.03 & tr. & tr. & tr. & 0.625 \\
\hline
\end{tabular}

In spite of the limited kinetics of the cementation process, the electron microprobe study proved that the cementation causes on the surface of iron particles gradual displacement of $\mathrm{Fe}^{2+}$ ions and precipitation of $\mathrm{Cu}^{2+}$ ions, both in form of $\mathrm{Cu}$-oxides, $\mathrm{Cu}$ carbonates and in form of native copper. The cementation copper is of a high fineness (it contain up to 96.07 wt. \%).

The $\mathrm{pH}-\mathrm{Eh}$ stability diagram for $\mathrm{Cu}-\mathrm{Fe}-\mathrm{S}-\mathrm{H}_{2} \mathrm{O}$ system (Fairthorne et al., 1997) show that formation of insoluble Fe oxides/hydroxides is possible both at neutral or alcaline $\mathrm{pH}$ and at high Eh values also in acid conditions (Figure 8). According to Fairthorne et al. (1997) the decrease in the amount of metal ions present in solution when the $\mathrm{pH}$ is increased and when nitrogen is replaced with oxygen is due to the formation of iron and copper oxides/hydroxides at the mineral (chalcopyrite) surface creating a physical barrier for further metal dissolution. The Eh value measured in this study at $\mathrm{pH} 5$ is very close to the separation line $\mathrm{Fe}^{2+} / \mathrm{Fe}_{2} \mathrm{O}_{3}$ when the mineral is 
conditioned in nitrogen but it moves away from this line in oxygen conditioning. The formation of insoluble cupric oxide/hydroxide is less thermo-dynamically favourable and only occurs at $\mathrm{pH}$ values larger than 6.

$\mathrm{The} \mathrm{Cu}$ in soil and in technogenous sediments is present mostly in $\mathrm{Cu}^{2+}$ form, less as a $\mathrm{Cu}^{3+}\left(\mathrm{Cu}_{2} \mathrm{O}_{3}\right.$ - stability field) and only in 2 cases in the elementary form $\left(\mathrm{Cu}^{0}\right) . \mathrm{Cu}$ from the surface water occupies several stability fields: $\mathrm{Cu}_{2} \mathrm{O}_{3}, \mathrm{Cu}^{0}, \mathrm{Cu}_{2} \mathrm{~S}, \mathrm{CuFeS}_{2}$ as well as $\mathrm{CuS}$ fields. Similar situation is in the case of the groundwater with exception of the $\mathrm{Cu}_{2} \mathrm{O}_{3}$ field (Figure 8). It means that the $\mathrm{Cu}$ in surface water is present in $\mathrm{Cu}^{0}, \mathrm{Cu}^{2+}$ and $\mathrm{Cu}^{3+}$ forms while in groundwater only in $\mathrm{Cu}^{0}$ and $\mathrm{Cu}^{2+}$ forms.

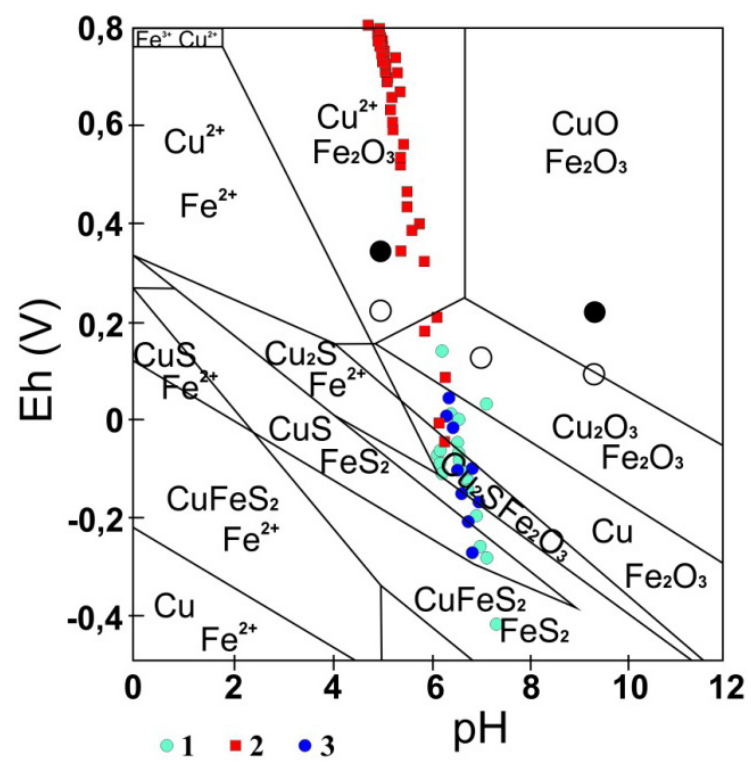

Figure 8. pH- Eh stability diagram for $\mathrm{Cu}-\mathrm{Fe}-\mathrm{S}-\mathrm{H}_{2} \mathrm{O}$ system (Fairthorne et al., 1997); (o) - the separation line $\mathrm{Fe}^{2+} / \mathrm{Fe}_{2} \mathrm{O}_{3}$ in nitrogen conditions and $(\bullet)$ - in oxygen conditions

The $\mathrm{Fe}$ in soil and in technogenous sediments is in the Eh-pH stability diagram for $\mathrm{Cu}-\mathrm{Fe}-\mathrm{S}-\mathrm{H}_{2} \mathrm{O}$ system (Fairthorne et al., 1997) situated only in the $\mathrm{Fe}_{2} \mathrm{O}_{3}$ stability field (Figure 8) or $\mathrm{Fe}(\mathrm{OH})_{3}$ stability field (Figure 9), in consequence of this finding it is possible presume that the $\mathrm{Fe}$ is present in $\mathrm{Fe}^{3+}$ form. In groundwater and in surface water was described mostly $\mathrm{Fe}^{3+}$ but less often also $\mathrm{Fe}^{2+}$ form (Figure 8).

The speciation of As (Figure 9) and $\mathrm{Sb}$ (Figure 10) indicate that there are present both $\mathrm{As}^{3+}, \mathrm{Sb}^{3+}$ and the less toxic $\mathrm{As}^{5+}, \mathrm{Sb}^{5+}$ species. In the sediments prevail $\mathrm{As}^{5+}$ and $\mathrm{Sb}^{5+}$ species.

Migration of $\mathrm{As}$ and $\mathrm{Sb}$ in water may be realised in form of acidic or basic oxyions $\mathrm{H}_{2} \mathrm{AsO}_{4}{ }^{-}, \mathrm{HAsO}_{4}{ }^{2-}$ and $\mathrm{HAsO}_{2}{ }^{0}$ or $\mathrm{SbO}_{3}{ }^{-}$and $\mathrm{SbO}_{2}{ }^{-}$under mildly oxidising conditions (Greenwood \& Earnshaw, 1990; Manning \& Goldberg, 2011). Under reducing, near-neutral to more alkaline conditions, transport of a sulphide complex such as $\mathrm{Sb}_{2} \mathrm{~S}_{4}{ }^{2-}$ is possible. By far the bulk of the stability field of water is covered by solid $\mathrm{Sb}$-species $\left(\mathrm{Sb}_{2} \mathrm{~S}_{3}\right.$, $\left.\mathrm{Sb}(\mathrm{OH})_{3}, \mathrm{Sb}_{2} \mathrm{O}_{4}, \mathrm{Sb}_{2} \mathrm{O}_{5}\right)$, thus suggesting that $\mathrm{Sb}$ transport must take place at moderately low Eh values.

At Lubietová are in the water dominant the $\mathrm{As}^{3+}$ and $\mathrm{Sb}^{3+}$ forms (Figures 9, 10). As ${ }^{3+}$ is much more mobile than $\mathrm{As}^{5+}$ (Greenwood \& Earnshaw, 1990; Manning \& Goldberg, 2011) in weathering zone. The high As content in the water is controlled by tetrahedrite (and arsenopyrite) decomposition and by As sorption on amorphous Fe oxides and oxyhydroxides, on clay minerals and hydrogoethite (Andráš et al., 2007). Antimony is under supergenous conditions mobile and it has very similar behavior as arsenic Vink (1966). Determination of antimony speciation enables $\mathrm{pH}$-Eh stability diagrams (Vink, 1966). Part of the anthropogenic sediment samples and soils are in the stability field of $\mathrm{SbO}_{3}{ }^{-}$water solution, the second part in senarmontite stability field (Figure 10). 


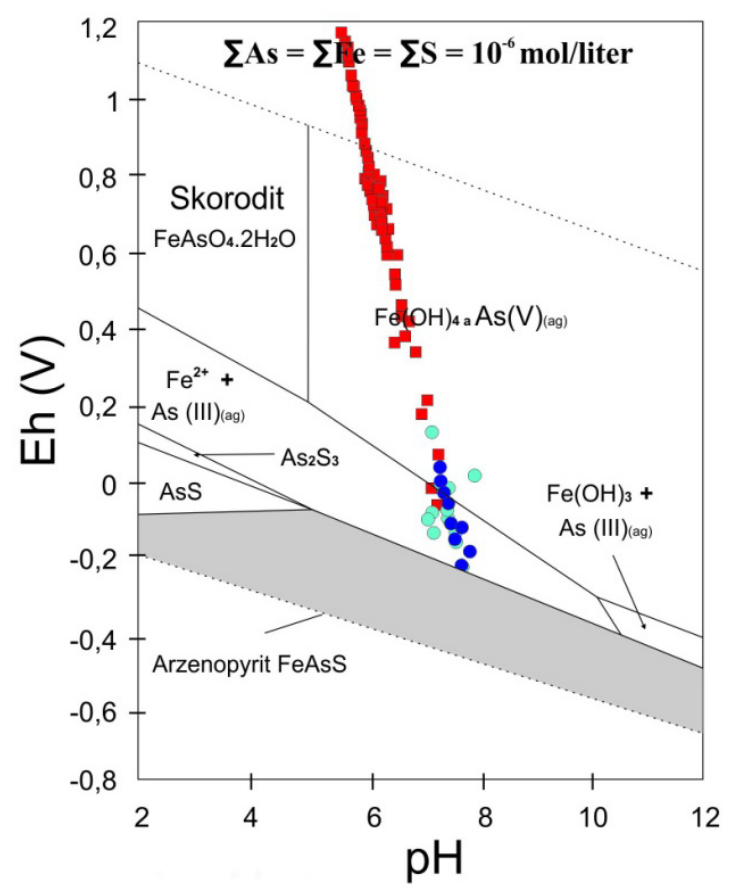

Figure 9. pH-Eh stability diagram of Fe-As- $\mathrm{H}_{2} \mathrm{O}-\mathrm{S}$ system according to Ryu (2002)

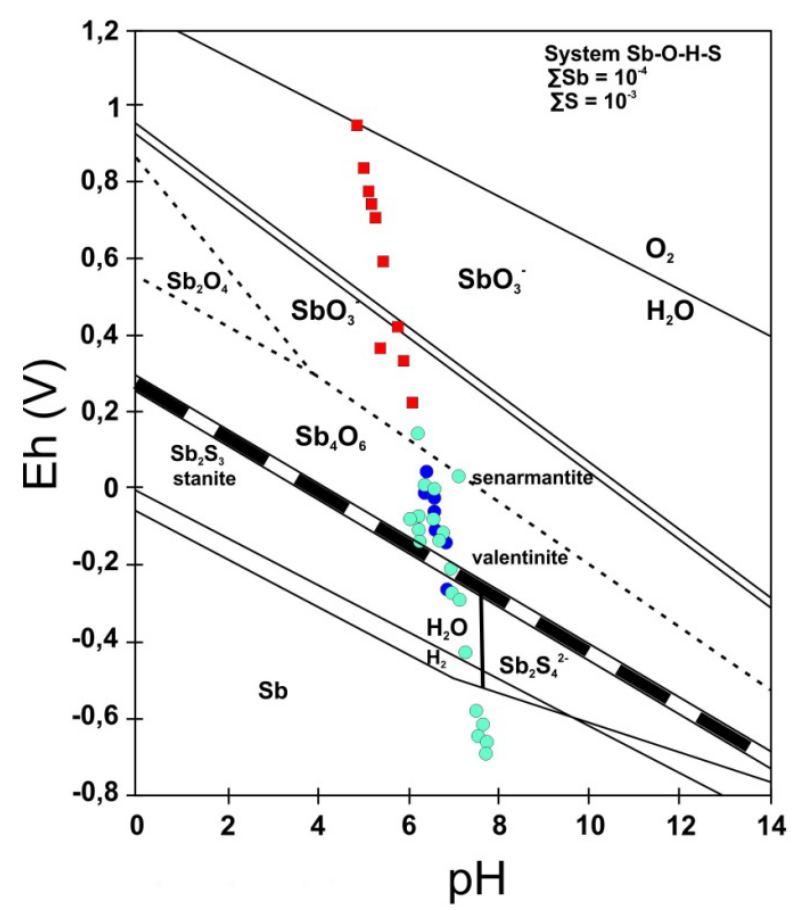

Figure 10. pH-Eh stability diagram of $\mathrm{Sb}-\mathrm{H}_{2} \mathrm{O}-\mathrm{S}$ system according to according to Vink (1966)

In groundwater, antimony is mainly present in the form $\mathrm{Sb}_{4} \mathrm{O}_{6}$. Only in one single sample we can find antimony in the form of elementary $\mathrm{Sb}^{0}$ and $\mathrm{Eh}$ as well as $\mathrm{pH}$ values of one sample are at diagram on the border between water solution and stibnite $-\mathrm{Sb}_{2} \mathrm{~S}_{3}$ (Figure 12). Also in surface water the dominant form of antimony is $\mathrm{Sb}_{4} \mathrm{O}_{6}$. Forms $\mathrm{SbO}_{3}{ }^{-}$and elementary $\mathrm{Sb}^{0}$ are very rare (Figure 12).

\subsection{Natural Sorbents}

Transport of heavy metals in form of mobile nanoparticles is influenced by natural sorbents. As the most important natural sorbents at the studied locality were described clay minerals (X-ray diffraction analyse proved 
presence of illite and muscovite mixture, caolinite but also minerals of smectite group and chlorite group) as well as hydrogoethite (Figure 11).

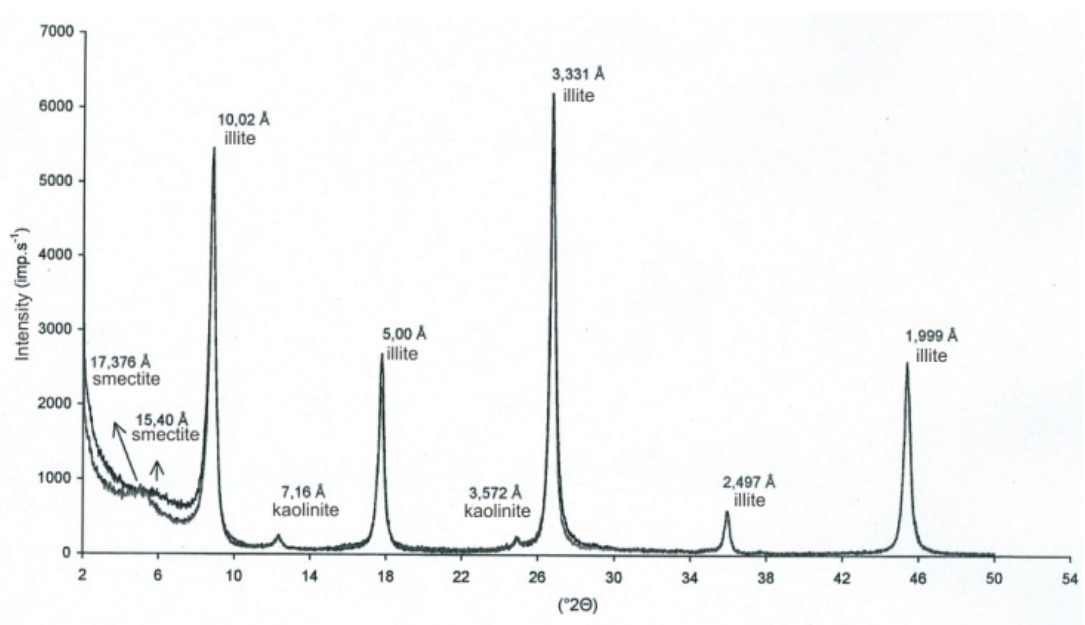

Figure 11. Rtg-diffraction diagram of clay mineral fraction from sample A-6

The best sorbent is hydrogoethite (Table 1, sample A-17). In most cases also the present clay minerals show good sorption capacity. These minerals generate in the dump-field material effective geochemical barrier which effect precipitation of metals and their fixation on the hydrogoethite and clay minerals surface.

Preferential sorption of $\mathrm{Cr}$ and $\mathrm{Th}$ on surface of clay minerals in comparison with hydroghoethite was described. On hydrogoethite surface are preferentially fixed $\mathrm{Cu}, \mathrm{Zn}( \pm \mathrm{Fe}, \mathrm{Cd}, \mathrm{Co})$.

Laboratory testing showed that most metals were sorpted on the clay minerals surface during 14 days maceration of the clay fraction in the drainage water percolating the dump-field material. This result indicates that the clay fraction still dispose by free sorption capacity.

Substantial differences in sorption capacity among various clay mineral mixtures were not certified, probably because of the matrix of all clay fraction consists predominantly of illite and muscovite. The variable quota of smectite, which has according to Andráš et al. (2007) higher sorption capacity as illite or muscovite, is not enough important to show substantially higher sorption efficiency.

\subsection{The Total Acid Potential of the Dump-Field and the Posibility of Remediation}

If distilled water is used in the measurement of paste or rinse $\mathrm{pH}$ of sediments or soils, its $\mathrm{pH}$ is usually around 5.3. $\mathrm{pH}$ values less than 5.0 indicates that the sample contains net acidity at the time of analyse (Sobek et al., 1978).

Values of paste $\mathrm{pH}$ between 5.0 and 10.0 can be considered near neutral at the time of the analysis. From the viewpoint of this study, only two samples (A-3 and A-12) account acid values (Table 5). It is surprising that one of these samples was taken from the reference area. The probable reason of such a behavior is the lack of carbonates (Table 5). The map of the soil and sediment acidity at the Podlipa dump-field is presented at Figure 12.

The measurement of the $\mathrm{pH}$ paste in the samples using solution of $1 \mathrm{M} \mathrm{KCl}$ gives similar values. It means that only several few samples show markedly acid reaction (Table 5).

The very low total carbon $\left(\mathrm{C}_{\text {tot. }}\right)$ content (Table 5) reflects the lack of carbonates. The Figure 13 shows the $C_{\text {tot. }}$ distribution and enable comparison with the map of the acidity (Figure 12).

The total acid potential (TAP) was calculated according to Sobek et al. (1978):

$$
T A P=\left(\% S_{\text {tot }}\right) \times 31.25
$$

where TAP is provided in any of three equivalent units: $\mathrm{kg} \mathrm{CaCO}_{3}$, equivalent/metric tone (t) of sample, $\mathrm{t} \mathrm{CaCO}_{3}$ equivalent/1000 $\mathrm{t}$ of sample, or parts per thousand (ppt) $\mathrm{CaCO}_{3}$ equivalent. 
The TAP values from the dump-field Podlipa range between 0.625 in samples A-12 (reference area) and A-2 to 13.125 in sample A-6 (Table 5).

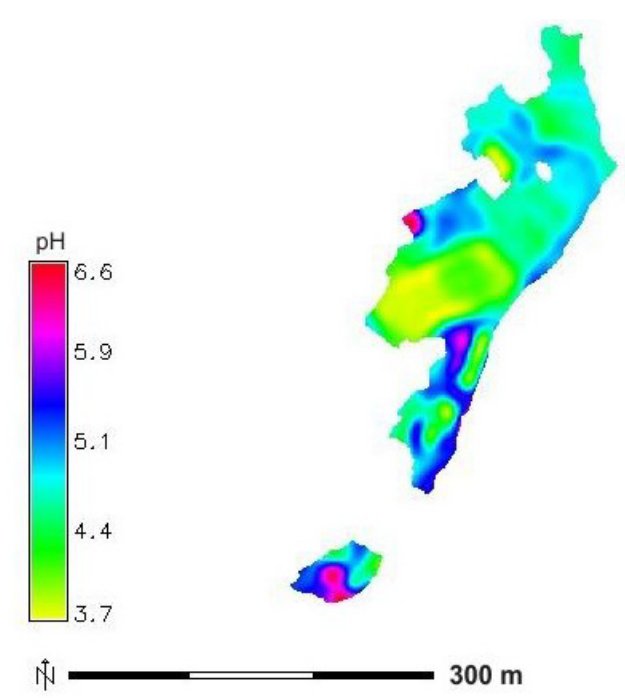

Figure 12. Map of the sediments acidity at the Podlipa dump-field
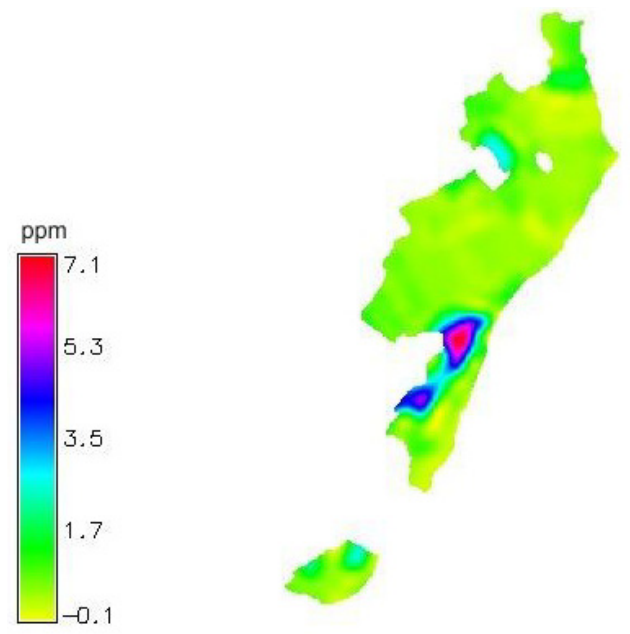

N $300 \mathrm{~m}$

Figure 13. Map of the Ctot, distribution in the sediments at the Podlipa dump-field

If we compare the highest TAP value for sample A-6 with the data about the sulphur content, we can demonstrate that both the highest sulphide and sulphate sulphur contents were described from this sample, which represents the sedimentary material from Zollweiner Maria Empfängnis adit. The highest TAP value is also the consequence of the relatively low carbon content.

The ability of drainage water to precipitate cementation copper on iron surfaces makes the realization of an $\mathrm{Fe}^{0}$-barrier for elimination of heavy metals $(\mathrm{Cu}, \mathrm{As}, \mathrm{Cd}, \mathrm{Zn}$ and others) from the contaminated water a possibility. Mixture of Fe chips with dolomite also allowed to eliminate the released Fe.

\subsection{Changes in Plant Tissues}

We studied in 2009 and 2010 the influence of the specific ecological conditions at dump-fields with high heavy metal content on selected plant species which represent tolerant ecotypes. The relatively common Pinus sylvestris show various defects of their tissues: exfoliation of summer tracheide cell-wall layers, formation of the traumatic resin channels in closeness to the calluses, absence of the cell-wall coarsening or presence of funguses 
hyphaes in tracheae (Figure 14).

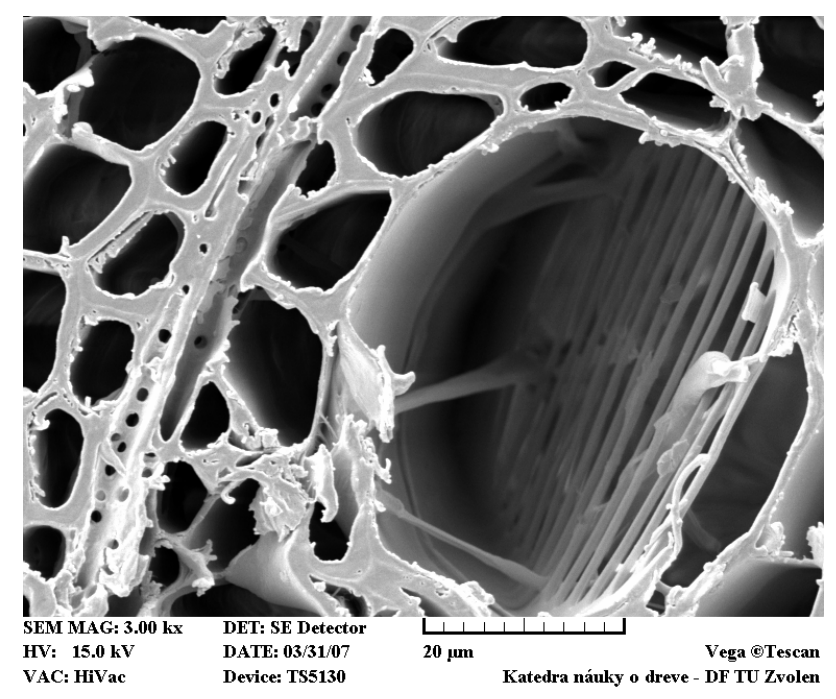

Figure 14. Funguses hyphaes in tracheae of Pinus sylvestris

Important chlorophyll insult causing even necrosis (mainly of leaves) was described in case of Acetosella vulgaris-plant which is considered to be so called ,exclude-plants which use exclusion mechanisms by which uptake and/or root-to-shoot transport of heavy metals are restricted (Adams et al., 2011) or associated metal-tolerant species, which are moderately tolerant of heavy metals in soil, but not dependent on their presence (Baker et al., 2010). At $150 \mathrm{~m}$ long sectors from base of the dumps to their top we found 19 to 37 individuals of this species and at each plant were described on leaves violet to necrotic spots (Figure 15). Plants damage at individual sectors varied in range $88-100 \%$.

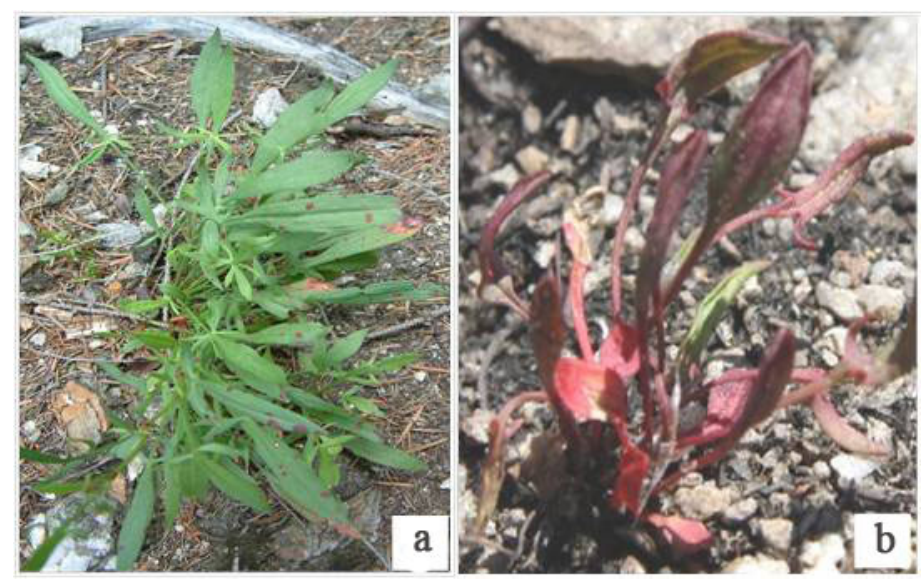

Figure 15. Violet to necrotic spots on leaves of Acetosella vulgaris. a) initial damage; b) complete change of the original colour

Typical nanistic-pygmy forms, drying of branches, reduced organs (leaves, fruits), yellowing leaves, short annual shoot and dense age-bands were described on plants from the dump-field area (e.g. on Picea abies, Pinus sylvestris, Larix decidua, Salix caprea, Betula pendula etc.). Site influence was statistically tested on size of Betula pendula leaves. For statistical analysis the STATISTICA 7.0 statistical package was used (StatSoft Inc., 2004). ANOVA test enabled evaluate differences in width of leave bases among individual plants on dump-field surface with those from reference area. Measuring of 50 individuals was realised from each locality. For each individual plant were measured on 10 leaves leave-blade bases from 8 pieces of one year old branches. Main descriptive characteristics of investigated set of plants both from dump-field and from reference area are presented in Table 6 . 
Table 6. Main descriptive characteristics of investigated set of plants

\begin{tabular}{ccc}
\hline & $\begin{array}{c}\text { Dump-field } \\
\text { Podlipa }\end{array}$ & $\begin{array}{c}\text { Reference } \\
\text { area }\end{array}$ \\
\hline Sample size & 400 & 400 \\
Arithmetic mean & 2.92 & 5.76 \\
Median & 2.87 & 5.74 \\
Mode & 2.61 & 5.71 \\
Variance / dispersion & 0.237 & 0.501 \\
Standard deviation & 0.487 & 0.708 \\
Minimum & 1.62 & 3.64 \\
Maximum & 5.23 & 11.05 \\
Range & 3.61 & 7.41 \\
\hline
\end{tabular}

Result of Least Significant Difference (LSD) shows statistically significant difference between the wide of base of birch leaves (it means also total size of leaves) from individuals of $\mathrm{Cu}$-dump field and reference locality with $\mathrm{p}<0.05$ (Table 7).

Table 7. Result of LSD with $\mathrm{p}<0.05$

\begin{tabular}{cccccc}
\hline Source & $\begin{array}{c}\text { Sum } \\
\text { of squares }\end{array}$ & Degrees of freedom & Mean square & $F$-ratio & $p$-value \\
\hline Between groups & 1618.82 & 1 & 1618.82 & 4386.38 & 0.000 \\
Within groups & 294.506 & 798 & 0.369 & & \\
Total & 1913.32 & 799 & & & \\
\hline
\end{tabular}

\section{Discussion}

Heavy metal distribution at the investigated dump-fields at L'ubietová reflect the geochemical behavior of the elements, depending on their content, solubility, migration potential and sorption properties (Cataldo \& Wildung, 1978). Hydrolysable metals (e.g., $\mathrm{Ni}, \mathrm{Cd}$ ) or metals forming insoluble precipitates with $\mathrm{S}$ or $\mathrm{P}$ on entering the soil in soluble forms may be expected to be rapidly insolubilised at the near neutral $\mathrm{pH}$ of most soils due to hydrolysis on dilution and subsequent precipitation on, or reaction with particle surfaces. Certain elements (e.g. Fe) may also form precipitates with S or P (Routson \& Wildung, 1969). The soil physicochemical parameters, most important in influencing the solubility of metals include: composition of solution, Eh, and $\mathrm{pH}$; type and density of charge on soil colloids; and reactive surface area (Keeney \& Wildung, 1977).

The main $\mathrm{Cu}$ sources at the dump-fields are sulphides (tetrahedrite and chalcopyrite) and secondary Cu-minerals (libethenite, langite, brochantite, pseudomalachite, malachite and azurite). $\mathrm{Cu}$ released to the solution during weathering processes, contaminates aqueous medium.

Mobility of the majority of heavy metals is in the nature mostly determined by their sorption on natural sorbents, which are mainly represented by clay minerals (Missana et al., 2008).

Kaolinite has been used as a good sorbent for most heavy metals (Wahba \& Zaghloul, 2007). Cu, Pb, Zn and Cd show favourable sorption on smectite and $\mathrm{Pb}$ also on illite surface (Rybicka et al., 1995). The uptake of $\mathrm{Pb}$ and $\mathrm{Cu}$ on illite and smectite is usually very fast. Kinetics of $\mathrm{Zn}, \mathrm{Ni}$ and $\mathrm{Cd}$ sorption on illite and smectite are not so efficient. $\mathrm{Mg}, \mathrm{Fe}$ and $\mathrm{Al}$ sorption on clay minerals is more efficient at higher $\mathrm{pH}$. It is caused by absence of free $\mathrm{H}^{+}$ions and by increase of negative charge on clay minerals surface (Kish \& Hassan, 1973). $\mathrm{pH}_{\left(\mathrm{H}_{2} \mathrm{O}\right)}$ of the technogenous sediments at Podlipa dump-fields ranges from 4,21 to 7,93 $\left(\mathrm{pH}_{(\mathrm{KCl})} 4.00-7.34\right)$, thus conditions for $\mathrm{Cu}, \mathrm{Pb}, \mathrm{Zn}$ and $\mathrm{Cd}$ adsorption on clay minerals are not the best but also not inefficient.

Thorium contents in clay minerals are amazingly lower than in the dump-sediment. It means that the Th is during the maceration washed out from the clays. This trend is noticeable because $\mathrm{U}$ is generally considered to be more mobile as Th (Polanski \& Smulikowski, 1978). The better mobility of U at the Lubietová deposit caused that while the content of Th in soil is several times higher than the content of U, while in plants (Andráš et al., 2007) is the $\mathrm{Th} / \mathrm{U}$ rate in consequence of better $\mathrm{U}$ mobility approximately identical (about $1: 1$ ). 
Acidity is mainly up to the geochemical behavior (weathering) of particular minerals (mainly pyrite). The calculation of the acid mine drainage water (AMD) formation potential (neutralisation potential, total acidity production, net neutralisation potential) is also discussed. The value of the net neutralisation potential (NPP) and the NP : AP ratio show that the potential of the acid mine drainage water formation is very limited (NPP $=1,42$; $\mathrm{NP}: \mathrm{AP}=1,72$ ) and the environmental risk is negligible.

Lack of carbonates at L'ubietová deposit causes that in 5 cases among 12 studied samples, are the NNP values negative (neutralisation matter is entirely absent) and two values (samples A-3 and A-11) are very low (7.4 and 20.1; Table 4). NNP values from -20 to $20\left(\mathrm{~kg} \mathrm{CaCO}_{3} \mathrm{t}^{-1}\right.$ of dump material) are possible to account as a "scale of uncertainty" sensu US EPA methodics (Lintnerová \& Majerčík, 2005) from viewpoint of the acidity production, because there is no unambiguous forecast if the AMD will be produced. In spite of this fact results of our study suggest that at Reiner and Podlipa is the assumption of AMD production very limited.

Mining dump surrounding is characterized by no or very poor and dry soil cover with lack of soil nutrinents, minimum of water combined with intensive evaporation, strong solifluction patterns and high heavy metal content. The plants growing at such as habitats are usually tolerant to a high metal content, characterized by high vitality and typical for xerothermic conditions.

As a symptom of heavy metal contamination is possible mention violet to red stigmas and necrosis on leaves and stems of vascular plants, nanic growth (Andráš et al., 2007; Chaves et al., 2011), reduction of roots (Banásová, 1976), chlorosis of leaves with green veining, growth stagnancy (Kopponen et al., 2001), drying of young branches and decrease of leaves size (Pulford \& Watson, 2003), ultrastructural effects (Ouzounidou et al., 1992).

Toxicity symptoms in plants from mining dumps (tendency for mould diseases, growth decrease, deformations of cell organelles and plant tissues, chlorosis of leaves) show sometimes similar features as influence of lack of essential elements. If the soil contains very high content of copper, we can in the plants see lack of Fe as a consequence of immobilisation of $\mathrm{Fe}$ by $\mathrm{Cu}$. As a result of Fe-lack we can see chlorosis of leaves, which could be caused also by superabundance of $\mathrm{Zn}$ (Kopponen et al., 2001). To state the unambiguous specification of toxicity reasons is necessary to have information about the heavy metal content in soil-plant system.

Betula pendula is the tree which represents the most important dynamic element on mining dumps and is considered as a focus of initial stages of vegetation due to litter formation, shadow and leeward (Banásová, 1976). Betula pendula is a suitable bioindicator of air pollution in urban areas (Samecka et al., 2009; Petrova, 2011) and it is used as a model organism in several studies focused on heavy metal influence on growth, annual additions and reproductive effort (Samecka et al., 2009; Franiel \& Babczynska, 2011). Our study also confirmed decrease of birch leave blades caused by heavy metal content.

\section{Conclusions}

The soil and technogenous sediments contamination is very irregular. It depends on the mineralogical composition of ores, on the original concentration of the mentioned metals in the technogenic sediments of the spoil dumps, and also on their migration abilities and sorption properties. Bilateral correlation of metals seems to be influenced by incorporation of elements to various metastable phases as well as by present natural sorbents. This proces is controlled both by oxidation state and by ionic radius of elements.

The surface water (and drainage water) as well as the groundwater water are substantially contaminated predominantly by $\mathrm{Cu}, \mathrm{Fe}, \mathrm{As}$ and $\mathrm{Sb}$. The content of the most dangerous contaminants: $\mathrm{As}^{3+}, \mathrm{As}^{5+}, \mathrm{Sb}^{3+}$ and $\mathrm{Sb}^{5+}$ don't pose acute risk. The only risk poses the spring of the mineral water Linhart because of the high radioactivity and high $\mathrm{Fe}, \mathrm{Cu}, \mathrm{Cd}$ and $\mathrm{Pb}$ contents.

The present natural sorbents are predominantly the clay minerals (illite, muscovite, caolinite, smectite) and hydrogoethite. The clay minerals are good sorbents of $\mathrm{V}, \mathrm{Cr}, \mathrm{Ti}, \mathrm{W}, \mathrm{Zr}, \mathrm{Nb}, \mathrm{Ta}$ a Th and at the hydrogoethite of $\mathrm{Cu}, \mathrm{Zn}, \mathrm{Mo}, \mathrm{Mn}, \mathrm{Mg},( \pm \mathrm{Fe}, \mathrm{Cd}, \mathrm{Co}, \mathrm{Ca})$. In the case of the $\mathrm{Fe}, \mathrm{As}, \mathrm{Sb}, \mathrm{Ag}, \mathrm{Pb}, \mathrm{Zn}, \mathrm{Mn}, \mathrm{Mo}, \mathrm{Bi}, \mathrm{U}$ was proved also the free sorption capacity.

The paste or rinse $\mathrm{pH}$ of sediments measured in distilled $\mathrm{H}_{2} \mathrm{O}$ is around 5.3 and only very few samples account acid values $(<5.0)$. Only several few samples show markedly acid reaction. The acidity production (AP) vary from 0.625 to 10.31 (in average 3.7) and the neutralisation potential ( $\mathrm{NP}^{-C a C O_{3}}$ ) from 0.66 to $12.71 \mathrm{kgtt}^{-1}$ (in average ca $27.1 \mathrm{kgt}^{-1} \mathrm{CaCO}_{3}$ ). The value of the net neutralisation potential (NNP) and the NP : AP ratio show that the potential of the acid mine drainage water formation is very limited $(\mathrm{NNP}=1.42 ; \mathrm{NP}: \mathrm{AP}=1.72)$ and the environmental risk is negligible.

The concentrations of the heavy metals in plant tissues decrease seriately in rate: $\mathrm{Fe}, \mathrm{Zn}, \mathrm{Pb}$ and $\mathrm{Cu}$. The highest concentrations of heavy metals are in roots, than in leaves and stems and the lowest concentrations are in flowers, 
seeds and in fruits. The plant tissues from the dump-field are heavily damaged. The results of the research document the plant defence reactions under the influence of stress factors at the dump sites (absence of soil and water, the heavy metal contamination, mobility of the cohesionless slope material).

Botanic research indicated that the specific conditions at the dump-fields have evident influence on plants. Some damage spots are visible even by naked eye but some of them were proved also statistically, by histological study of Pinus sylvestris and by evaluation of morbid changes of Acetosella vulgaris.

The Lubietová-Podlipa dump-field dispose by certain degree of "self-cleaning ability". Important part of the heavy metals and contaminants is fixed in porous dump-material, Fe-hydroxides and in clay minerals (mainly illite, caolinite, smectite and chlorite group), which show still an important free sorption capacity. The ability of the drainage water precipitate cementation copper (as well as $\mathrm{Sb}$ and probably also other heavy metals as As) on the iron surface give possibility to realize $\mathrm{Fe}^{0}$-barrier for elimination of heavy metals from the groundwater and drainage water.

\section{Acknowledgements}

This work was supported by grant contracts VEGA 2-0065-11 and APVV-0663-10. We would like to thank Ján Ostrolúcky and Ján Tomaškin for help with field work and statistical analyses. This paper has been elaborated in the framework of the project Opportunity for young researchers, reg. no. CZ.1.07/2.3.00/30.0016, supported by Operational Programme Education for Competitiveness and co-financed by the European Social Fund and the state budget of the Czech Republic.

\section{References}

Adams, J. P., Adeli, A., Hsu, C. Y., Harkess, R. L., Page, G. P., Schultz, E. B., \& Yuceer, C. (2011). Poplar maintains zinc homeostasis with heavy metal genes HMA4 and PCS1. Journal of experimental botany, 62(11), 3737-3752. http://dx.doi.org/10.1093/jxb/err025

Andráš, P., Mamoňová, M., Ladomerský, J., Turisová, I., Lichý A., \& Rusková, J. (2007). Influence of the dump sites on development of selected plant tissues at the L'ubietová area (Slovakia). Acta Facultatis Ecologiae, 16(1), 147-158.

Baker, A. J. M., Ernst, W. H. O., van der Ent, A., Malaisse, F., \& Ginocchio, R. (2010). Metallophytes: the unique biological resource, its ecology and conservational status in Europe, central Africa and Latin America. In L. C. Batty \& K. B. Hallberg (Eds.), Ecology of industrial pollution (pp. 7-40). Cambridge: Cambridge University Press. http://dx.doi.org/10.1017/CBO9780511805561.003

Banásová, V. (1976). Vegetácia medených a antimónových háld (Vegetation of copper and antimony mine heaps). Biologické Práce, 22, 1-109.

Bartzas, G., Komnitsas, K., \& Paspaliaris, I. (2006) Laboratory evaluation of $\mathrm{Fe}^{0}$ barriers to treat acidic leachates. Minerals Engineering, 19(5), 505-514. http://dx.doi.org/10.1016/j.mineng.2005.09.032

Bergfest, A. (1951). Baníctvo v Lubietovej na medenú rudu. Banská Štiavnica: Ústredný banský archív pre Slovensko-Central Mining Archive.

Cataldo, D. A., \& Wildung, R. E. (1978). Soil and plant factors influencing the accumulation of heavy metals by plants. Environmental Health Perspectives, 27, 149-159. http://dx.doi.org/10.1289/ehp.7827149

Chaves, L. H. G., Estrela, M. A., \& de Souza, R. S. (2011). Effect on plant growth and heavy metal accumulation by sunflower. Journal of Phytology, 3(12), 4-9.

Ebner, F., Pamić, J., Kovács, S., Szederkenyi, T., Vai, G. B., Venturini, C., ... Mioć, P. (2004). Variscan Preflysch (Devonian-Early Carboniferous) environments. Tectonostratigraphic Terrane and Paleoenvironment Maps of the Circum-Pannonian Region, 1(2,500,000).

Fairthorne, G., Fornasiero, D., \& Ralston, J. (1997). Effect of oxidation on the collectorless flotation of chalcopyrite. International Journal of the Processes, 49(1-2), 31-48. http://dx.doi.org/10.1016/S0301-7516(96)00039-7

Franiel, I., \& Babczyńska, A. (2011). The Growth and Reproductive Effort of Betula pendula Roth. In a Heavy-Metals Polluted Area. Polish Journal of Environmental Studies, 20(4), 1097-1101.

Greenwood, N. N., \& Earnshaw, A. (1990). Chemie der Elemente. Würzburg: VCH Verlagsgesellschaft mbH.

Keeney, D. R., \& Wildung, R. E. (1977). Chemical properties of soils. In L. Elliott \& R. J. Stevenson (Eds.), Soils for Management of Organic Wastes and Waste (pp. 75-100). Madison, Wisconsin: American Society 
of Agronomy.

Kishk, F. M., \& Hassan, M. N. (1973). Sorption and desorption of copper by and from clay minerals. Plant Soil, 39(3), 497-505. http://dx.doi.org/10.1007/BF00264168

Koděra, M. (1990). Topografická mineralógia 2. Bratislava: Veda, SAV.

Kopponen, P., Utriainen, M., Lukkari, K., Suntioinen, S., Kärenlampi L., \& Kärenlampi, S. (2001). Clonal differences in copper and zinc tolerance of birch in metal-supplemented soils. Environmental Pollution, 112(1), 89-97. http://dx.doi.org/10.1016/S0269-7491(00)00096-8

Lintnerová, O., \& Majerčík, R. (2005). Neutralizačný potenciál sulfidického odkaliska Lintich pri Banskej Štiavnici-metodika a predbežné hodnotenie (Neutralisation potential of tailing of sulphide deposit at Lintich near Banská Štiavnica). Mineralia Slovaca, 37(4), 17-28.

Manning, B. A., \& Goldberg, S. (1997) Adsorption and stability of Arsenic(III) at the clay mineral-water interface. Environmental Science \& Technology, 31(7), 2005-2011. http://dx.doi.org/10.1021/es9608104

Missana, T., Garcia-Guttierez, M., Alonso, U. (2008). Sorption of strontium onto illite/smectite mixed clays, Physics and Chemistry of the Earth, 33(Sup. 1.1), 156-162.

Morin, K. A., \& Hutt, N. M. (1997). Environmental geochemistry of minesite drainage: Practical Tudory and case studies. Vancouver: MDAG Publishing.

Ouzounidou, G., Eleftheriou, E. P., \& Karataglis, S. (1992). Ecophysical and ultrastructural effects of copper in Thlaspi ochroleucum (Cruciferae). Canadian Journal of Botany, 70(5), 947-957. http://dx.doi.org/10.1139/b92-119

Petrova, S. T. (2011). Biomonitoring Study of Air Pollution with Betula pendula Roth. from Plovdiv, Bulgaria. Ecologia Balkanica, 3(1), 1-10.

Polański, A., \& Smulikowski, K. (1978). Geochémia. Bratislava: Slovenské pedagogické nakladatel'stvo.

Pulford, I. D., \& Watson, C. (2003). Phytoremediation of heavy metal-contaminated land by trees - a review. Environment International, 29(4), 529-540. http://dx.doi.org/10.1016/S0160-4120(02)00152-6

Routson, R. C., \& Wildung, R. E. (1969). Ultimate disposal of wastes to soil. Chemical Engineering Progress, Symp. Ser., 65(97), 19-25.

Rybicka, E. H., Calmano, W., \& Breeger, A. (1995). Heavy metals sorption/desorption on competing clay minerals; an experimental study. Applied Clay Science, 9(5), 369-381. http://dx.doi.org/10.1016/0169-1317(94)00030-T

Ryu, J., Gao, S., Dahlgren, R. A., \& Ziernberg, R. A. (2002) Arsenic distribution, speciation and solubility in shallow groundwater of Owens Dry Lake, California. Geochimica et Cosmochimica Acta, 66(17), 2981-2994. http://dx.doi.org/10.1016/S0016-7037(02)00897-9

Samecka-Cymerman, A., Kolon, K., \& Kempers, A. J. (2009). Short shoots of Betula pendula Roth. as bioindicators of urban environmental pollution in Wrocław (Poland). Trees - Structure and Function, 23(5), 923-929. http://dx.doi.org/10.1007/s00468-009-0334-Z

Sobek, A. A., Schuller, W. A., Freeman, J. R, \& Smith, R. M. (1978). Field and laboratory methods applicable to overburden and minesoils. EPA 600/2-78-054.

StatSoft, I. N. C. (2004). STATISTICA (data analysis software system), version 7. Computer software. Retrieved from www.statsoft. com

Vink, B. W. (1966). Stability relations of antimony and arsenic compounds in the light of revised and extended Eh-pH diagrams. Chemical Geology, 130(1-2), 21-30. http://dx.doi.org/10.1016/0009-2541(95)00183-2

Wahba, M. M., \& Zaghloul, A. M. (2007). Adsorption Characteristics of Some Heavy Metals by Some Soil Minerals. Journal of Applied Sciences Research, 3(6), 421-426.

\section{Copyrights}

Copyright for this article is retained by the author(s), with first publication rights granted to the journal.

This is an open-access article distributed under the terms and conditions of the Creative Commons Attribution license (http://creativecommons.org/licenses/by/3.0/). 